To cite this article: W. A. Adriansyah, B. O. Y. Marpaung and D Lindarto (2021). WASTE MANAGEMENT PLANNING MODEL BASED ON COMMUNITY PARTICIPATION IN URBAN FOREST PARK, LANGSA, ACEH, International Journal of Education and Social Science Research (IJESSR) 4 (6): 114-130

\title{
WASTE MANAGEMENT PLANNING MODEL BASED ON COMMUNITY PARTICIPATION IN URBAN FOREST PARK, LANGSA, ACEH
}

\author{
W. A. Adriansyah ${ }^{1}$, B. O. Y. Marpaung ${ }^{2}$ and D Lindarto ${ }^{3}$ \\ ${ }^{1}$ Master's Degree Program of Architecture, Faculty of Engineering, \\ Universitas Sumatera Utara, Medan, Indonesia \\ ${ }^{2}$ Master's Degree Program of Architecture, Faculty of Engineering, \\ Universitas Sumatera Utara, Medan, Indonesia \\ ${ }^{3}$ Master's Degree Program of Architecture, Faculty of Engineering, \\ Universitas Sumatera Utara, Medan, Indonesia
}

DOI: http://dx.doi.org/10.37500/IJESSR.2021.4610

\begin{abstract}
Langsa city forest is made into a Green Open Space with an area of 6 hectares located in Kampung Paya Bujok Bromo, Langsa City. As one of the leading recreational areas in Langsa City, City Forest Park provides comfort for people who visit for recreation. Cleaning facilities are one of the supporting factors in the form of a trash can that provides a comfortable environment when visitors throw garbage. Handling waste management based on community participation in development can be accommodated using a community development approach. The low community participation in waste management and the lack of facilities that support community participation in waste management. This study aims to analyze community participation in waste generation management and to plan waste facilities based on community participation. By using a qualitative research method with a descriptive approach to reveal the situation of user behavior in the context of waste generation management, before, during, and after waste generation in Urban Forest Park Langsa. The results of this study are expected to be a guide in planning community participation-based waste management.
\end{abstract}

KEYWORDS: garbage, waste management, urban forest, participation.

\section{INTRODUCTION}

World-class waste production has produced 1.3 billion tons per year [1]. Waste capacity will continue to increase along with the growth of the city's population. Waste management of up to 200,000 tons per day is a problem for Indonesia as the fourth most populous country in the world [2]. Waste generation based on data from the BPS for Aceh Province in 2019 reached 972,312 tons per year. Meanwhile, the waste generation in Langsa City as one of the largest cities according to BPS data from the Aceh Province in 2019 reached 34,574 tons per year. The amount of waste produced in Urban Forest Park, Langsa is 12 tons per year. Langsa City has established an urban forest park as a recreation 
area with $\pm 15,000$ visitors. The growth rate of waste originating from tourists increases with the number of visitors.

Handling waste management based on community participation in development can be accommodated in several ways, one of which is by using a community development approach [3]. The community development method is used to get community participation which causes waste problems in Urban Forest Park, Langsa. Wet waste in Urban Forest Park, Langsa is caused by people who trade in the urban forest canteen. The community sells chicken penyet rice, fried rice, Aceh noodles, coffee, and various processed foods/drinks then throws the waste into the trash cans that do not have a separator label in the canteen area. The management provides a special canteen area for visitors who want to enjoy the area while eating and drinking. Dry waste is produced by sellers who sell along with the main accessibility in Urban Forest Park, Langsa. People who sell in Urban Forest Park, Langsa in the form of snacks, snacks/drinks, children's toys, and souvenirs. Visitors who buy waste from these sellers in several urban forest facilities include park benches, resin tree community areas, zoo areas, and waste disposal that does not match the color separation label of the trash can provided by the manager. B3 waste (Toxic and Hazardous Materials) in Urban Forest Park, Langsa is produced by managers and sellers who sell in the canteen. The use of garden lights in the form of bulbs/TL and batteries used throughout Urban Forest Park, Langsa causes B3 waste in Urban Forest Park, Langsa.

People participating can be distinguished in several hierarchical levels. The level of community participation in development programs implemented by the government into 8 (eight) levels of community participation which are very well known which are based on the power given to the community [4]. The participation rates from highest to lowest are as follows:

1. Citizen control, namely the community can participate in and control the entire decision-making process. At this level, the community has the power to regulate programs or institutions related to their interests. The community has the authority and can negotiate with outside parties who want to make changes. This joint effort of residents is directly related to the source of funds to obtain assistance without going through a third party;

2. Delegated power, namely at this level the community is given the authority to make decisions on certain plans. To solve problems, the government must negotiate with the community without pressure from above, it is possible for the community to have a level of control over government decisions;

3. Partnership, namely the community has the right to negotiate with decision-makers or the government, by mutual agreement power is shared between the community and the government. For this reason, an agreement was taken to share responsibilities in planning, controlling decisions, formulating policies, and solving problems encountered; 
4. Placation, namely the power holder (government) needs to appoint a number of people from the affected part of society to become members of a public body, where they have certain access to the decision-making process. Although in its implementation the community's proposals are still considered, due to their relatively low position and fewer in number than members of the government, they are unable to make decisions;

5. Consultation, namely that the public is not only notified but also invited to share opinions, although there is no guarantee that the opinions expressed will be taken into consideration in decision making. The methods that are often used are surveys on the direction of people's thoughts or community environmental meetings and public hearings or hearings with the community;

6. Informing, namely the power holder only provides information to the public regarding the activity proposal, the community is not empowered to influence the results. Information may include rights, responsibilities, and options, but there is no feedback or negotiating power from the community. Information is provided at the final stages of planning and the community has little opportunity to influence the plans that have been drawn up;

7. Therapy, namely the power holder gives reasons for the proposal by pretending to involve the community. Although involved in activities, the aim is more to change the mindset of the community than to get input from the community itself;

8. Manipulation is the lowest level of participation, where people are only used by name. Activities to manipulate information to gain public support and promise a better situation even though it will never happen.

From the hierarchy of levels of participation proposed by Arnstein, they are grouped into 3 (three) major groups, namely no participation at all (non-participation), which includes: manipulation and therapy; community participation in the form of residence receiving several provisions (degrees of tokenism), including informing, consultation, and placation; (3) community participation in the form of having power (degrees of citizen power), including partnership, delegated power, and citizen power.

Levels of Participation which is one of the field practitioners in the field of participatory planning in Indonesia [5], groups the level of community participation into 3 (three) parts, namely:

1. High. This can be seen from the initiatives that come from the community and are carried out independently starting from the planning, implementation to the maintenance of development results. The community does not only participate in formulating the program but also determines the programs to be implemented 
2. Medium. This can be seen from the community that has participated, but in practice, it is still dominated by certain groups. The community can voice their aspirations, but they are still limited to daily problems

3. Low. The community only witnessed project activities carried out by the government. The public can provide input either directly or through the mass media, but only for consideration. The community is still very dependent on funds from other parties so that if the funds stop, activities will stimulants stop as well.

Based on the phenomena in the field, the main problems of solid waste in the field are the low participation of the community in waste management and the lack of facilities that support community participation in waste management, so research is needed on "A Model of Waste Management Based on Community Participation in Urban Forest Park, Langsa, Aceh." This research is expected to be useful for the community, namely so that cleanliness, health, and comfort in enjoying the Urban Forest Park, Langsa are increasing.

\section{METHODS}

The type of research used is a qualitative research method with a descriptive approach. The method of combining qualitative research approaches can answer the findings of the research entitled Community Participation-Based Waste Management Planning Model in Urban Forest Park, Langsa, Aceh. A qualitative approach can be used if you want to see and express a situation or object in its context; find a deep meaning or understanding of a problem at hand that appears in the form of qualitative data, in the form of pictures, words, and events as well as in a "natural setting" [6]. The qualitative method is a research process that produces descriptive data in the form of written or spoken words from the observed actors [7]. Based on this understanding, it can be said that qualitative methods are used to determine the goals to be achieved through understanding a phenomenon experienced and carried out by research subjects to provide input in the form of motivation, action, and others. In other words, the qualitative method as a whole describes all forms of words and language using various natural methods so that it can be useful for those who use the research results and will affect the results to be achieved.

The researcher wants to reveal the situation of user behavior in the context of waste generation management, in this case as a context qualitative research methods are used. The qualitative method is following this study because it is used to determine the objectives to be achieved through an understanding of user behavior in managing waste generation in Urban Forest Park, Langsa.

\section{RESULTS AND DISCUSSION}

Community participation in the management of waste generation in Urban Forest Park, Langsa by reanalyzing the research instrument. The instrument to be analyzed for the problem of waste generation is the color classification of the trash can in the City Forest Park area. Waste management in the tourist area of Malioboro Jogjakarta based on community participation according to its type, the following alternative designs are proposed: adding types of waste (organic waste, inorganic waste, B3 waste) in 
the trash [8]. In addition to classifying the types of trash cans that will be placed in tourist areas, color labeling is also carried out to facilitate waste sorting. This is based on the management of waste generation in tourist areas in the Kinantan Cultural and Wildlife Park (TMSBK) and Japanese Panorama and Hole Park (TPLJ) Tourism Areas in Bukit Tinggi City [9]. High by providing garbage containers with different colors, namely green for compostable waste, yellow for recyclable waste, and red for other waste.

Based on the results of the analysis of some waste management problems that are not by the waste management design in Urban Forest Park Langsa tourist area, based on field observations, several problems were found. These problems include the classification of containers/bins in waste generation management, namely the provision of color labels and the addition of writing on 4 (four) containers/barrels at several points in Urban Forest Park, Langsa area. Classification of 4 (four) trash containers/bins, namely green for organic waste, yellow for inorganic waste, blue for paper waste, and red for B3 waste (in the form of hazardous materials). Classification 4 (four) trash bins/portable trash cans are placed in a single framework that is not located throughout the Urban Forest Park Langsa area.

Number equations consecutively with equation numbers in parentheses flush with the right margin, as in (1). First, use the equation editor to create the equation. Then select the "Equation" markup style. Press the tab key and write the equation number in parentheses. Data verification in qualitative research is needed to test or check the accuracy of the data that has been collected from the research process. As for the verification of data in this study, namely using the following procedure. Researchers return to the field to make observations to find out the truth of the data obtained and find new data. a series of activities that are structured and carried out seriously and continuously on all the realities that exist in the research location and to find characteristics and elements in situations that are very relevant to the problem or event being sought and then focused in detail by doing perseverance in-depth observation. So in this case the researcher is expected to be able to describe in detail the continuous process of how the detailed discovery can be carried out. Triangulation is defined as a data collection technique that combines various data collection techniques and existing data sources. The purpose of triangulation is not to find the truth about some phenomena but rather to increase the researcher's understanding of what has been found. In this study, researchers used one kind of triangulation, namely source triangulation.

\subsection{Observation of participant on waste generation management}

Observations were made based on 3 (three) sources that were the subject of research on the causes of waste generation in the Urban Forest Park Langsa area. The community that became the subject consisted of managers, visitors, and sellers who were in Urban Forest Park Langsa area. Nonparticipatory observation is used to obtain data on individual/group behavior to be observed to obtain analysis results from observations of waste generation problems in Urban Forest Park Langsa. 
Based on the results of the researcher's analysis of some problems that are not by the design standards for handling waste generation by conducting field observations to managers in the Urban Forest Park Langsa area. The analysis resulted in the problem of management participation in waste generation management when the manager was at the entrance to the area both from the main gate and from the back gate. The participation of the manager in the management of waste generation while in the shaded area, as well as the participation of the manager in the management of waste generation when the manager will leave the Urban Forest Park Langsa area.

\section{a. Observations on management participation}

Several obstacles were encountered when observing the participation of managers in managing waste generation when entering the Urban Forest Park Langsa area. The problem obtained by the manager in managing waste generation is in the main gate area to enter the area. The main gate area will enter the area and also in the back gate area to enter the Urban Forest Park Langsa area which is the beginning of the management's participation in waste generation in Urban Forest Park Langsa. Based on field observations of the types of waste produced by the manager when entering the area, it turned out that it was not only paper waste that was torn up by tickets. The manager also produces food and beverage waste which is disposed of in the unit's trash/container without any separation of types of waste. The manager's participation in the management of waste generation when entering the area is an initial problem based on the observations of researchers.

Problems obtained by managers in managing waste generation in almost all areas. The area includes the gazebo area, canteen/canteen area, mini zoo, Rumoh Aceh area, parking area, counter area (main door and back gate), ATV area, riding area, an area under resin trees/old trees, wall climbing area, and toilet areas. The participation of managers in dealing with the problem of waste generation is still low. This can be seen based on field observations conducted by researchers. The participation of managers in the Urban Forest Park Langsa area is still low because it only provides one unit of container/trash can and 4 containers with irregular color labels. All waste in the area is still integrated with the type of waste, both by visitors and sellers, both in individual trash containers/bins and those that have been labeled. This is because the management's participation in classifying waste types has not been implemented in the Urban Forest Park Langsa area. The provision of trash containers/bins in a series of portable trash bins is still very confusing for people who visit the area.

Several problems were encountered when observing the participation of managers in managing waste generation when leaving the Urban Forest Park Langsa area. The problem obtained by the manager in the management of waste generation is from the parking area to the exit area. The problem is in the parking area to get out of the Urban Forest Park Langsa area where the participation of managers in dealing with the problem of waste generation is still low. This can be seen based on field observations conducted by researchers. Manager participation when leaving the Urban Forest Park Langsa area is still low because it only provides individual trash containers/bins. All the waste generated when leaving the area is still put together in one container. The participation of managers in classifying the 
types of waste when leaving Urban Forest Park Langsa has not been carried out at all. Based on observations in the field, the types of waste produced by the manager when leaving the area with various types of waste produced. Management of waste generation when leaving an area that only has one storage unit is also one of the problems in managing waste generation in the Urban Forest Park Langsa area.

\section{b. Observations on visitor participation}

Researchers have analyzed the problem of visitor participation in waste generation management in Urban Forest Park Langsa. The analysis that has been observed by researchers results in the problem of visitor participation in the management of waste generation when visitors enter the Urban Forest Park Langsa area. Problem analysis: The participation of visitors in the management of waste generated in the area and the participation of visitors in the management of waste generation when visitors leave the Urban Forest Park Langsa area. Visitor participation in waste generation management is very low due to differences in the level of motive, purpose, age, education, economy, and socioculture of visitors as people who travel to the Urban Forest Park Langsa area.

The participation of visitors to the Urban Forest Park Langsa area to dispose of waste according to the color label and the type of waste up to 4 (four) containers/barrels in the City Forest Park area is still very low. This is because the level of awareness of visitors is still low. Visitor participation in waste generation management is still low because visitors have not been socialized, given an appeal or direction to classify the type of waste based on the labeling of the waste container provided by the manager. Visitor participation is still low because visitors' ignorance about the classification of types of waste in labeled trash containers is also one of the supporting factors.

The participation of visitors when leaving the Urban Forest Park Langsa area is still low because the waste generated by visitors is disposed of in the garbage collection unit provided by the manager. The participation of visitors in the management of waste generation when leaving the area is still united in one container/trash can. This is due to the lack of management participation in classifying types of waste when leaving the Urban Forest Park Langsa area which has not been carried out at all, especially in the parking area for 4-wheeled vehicles or buses.

\section{c. Observations on seller participation}

Based on the results of the researcher's analysis of some problems that are not by the design standards for handling waste generation by conducting field observations of sellers in the Urban Forest Park Langsa area. The analysis resulted in the problem of sellers' participation in the management of waste generation when sellers entered the Urban Forest Park Langsa which had been shaded. Problem analysis the participation of sellers in the management of waste generation while in the shaded area, as well as the participation of sellers in the management of waste generation when sellers leave the Urban Forest Park Langsa area that has been shaded. The analysis is based on the participation of 
sellers in the overall management of waste generation, namely in the canteen in the Urban Forest Park Langsa area.

There were no obstacles encountered when observing the participation of visitors in the management of waste generation when entering the Urban Forest Park Langsa area. Visitors have various motives and purposes in the Urban Forest Park Langsa Area. Visitors who visit the area do not only come from Langsa City but various regions. Visitors have different socio-economic and cultural conditions so that they have different levels of participation in waste generation management in the Urban Forest Park Langsa area. In addition, the level of education of visitors also affects the level of participation in waste generation management in the Urban Forest Park Langsa area. The seller peddles their wares in places provided by the manager and there are also street vendors selling deer food at several points in the mini zoo area. Sellers in the mini zoo area do not produce waste because it is in the form of carrots/vegetables to be bought by visitors and then given to the deer that are inside the fence of the mini zoo area. It can be said that those who sell their wares in the mini zoo area are a zero-waste area for sellers' waste in the Urban Forest Park Langsa area.

All the waste produced by sellers in the area is still put together in one trash can. Even the participation of managers in classifying types of waste based on the color of the container/bin is not uniform at all. The provision of trash cans/trash cans in the area already has a color label and writing on the type of trash/garbage can but it doesn't work. Sellers dispose of their wares by uniting all types of waste generated in a series of containers/bins. The seller's participation in reducing waste generation when leaving the Urban Forest Park Langsa area is the seller's right. Integrated into a single unit of waste generation in containers/bins provided by the manager or taken out of the area to be sold to collectors of used goods. However, based on observations in the field, it was found that the sellers did not dispose of cardboard packaging waste in the area but took it outside the area.

\subsection{Interview of participant on waste generation management}

The next stage of analysis is that researchers use interview techniques to obtain useful information. The observation technique through interviews is to ask someone or an informant about the incidence of waste generation in the Urban Forest Park Langsa area. At this stage, the researchers compiled questions for informants who were in the tourist area, namely managers, visitors, and sellers who produced waste in the Urban Forest Park Langsa area. At this stage, the researchers will conduct interviews and discussions to obtain data information about the management of waste generation before, during, and after waste generation in tourist areas.

\subsection{Documentation of participant on waste generation management}

The documentation obtained came from identified informants, to obtain photos of participation in the management of waste generation generated by the community living in the Urban Forest Park Langsa area. Waste generation management documentation to describe the results of the analysis of several waste management problems that are not by the waste management design standards in the Urban 
Forest Park Langsa Area. The research instrument is field documentation using drone photos and smartphone photo cameras. Aerial photo data using a drone with a shooting height of 250 meters, a flight duration of 28 minutes, and a flying speed of $15 \mathrm{~m} / \mathrm{s}$ to obtain documentation of the research location as a whole. The community that became the subject consisted of managers, visitors, and sellers who were in the Urban Forest Park Langsa area.

\section{a. Documentation on management participation}

The results of the analysis found several problems during field documentation regarding the participation of managers in managing waste generation when entering the area, while inside the area, and when leaving the area that was not following the standard for handling waste generation to be resolved. in Urban Forest Park Langsa.

Management participation in waste generation management is very low because managers have various functions within the area, including ticket officers, parking officers, security officers, managers, and the backbone of waste generation management in the area, namely cleaning officers. The ticket officer generates garbage in the area next to the ticket booth which is in the back area of the area as an alternative to the second entrance to the Urban Forest Park Langsa Area.

Waste segregation is not carried out by managers in this area at all to overcome the problem of waste generation caused by managers in the Urban Forest Park Langsa area. Even the location of the garbage that has piled up into one is very difficult to reach by the cleaners who are part of the management in the Urban Forest Park Langsa Area. Visitors who enter the area from the back door access park their vehicles in the parking area managed by the community which is behind the Urban Forest Park Langsa area. After buying an entrance ticket, visitors hand over the entrance ticket to the manager at the gate to be torn up as a sign that the management officer has verified that they can enter the area. The former torn from the manager must be kept back by visitors as proof of ticket ownership for the condition to leave the Urban Forest Park Langsa area.

\section{b. Documentation on visitor participation}

Analysis of community participation, namely visitors who are in the area that produce waste when entering the area, while inside the area, and when leaving the area. The level of visitor participation will be analyzed for waste generation management in the Urban Forest Park Langsa area.

Management of waste generation is still low because visitors have never been socialized, given counseling or directions about classifying types of waste based on the labeling of containers/bins provided by the manager. Even though the existing trash containers/bins have been labeled with color, visitors still dispose of their trash on the lids of the containers/trash cans provided by the manager. The participation of visitors in maintaining environmental cleanliness is a major problem in the management of waste generation in the Urban Forest Park Langsa area. 
Visitors are still thinking about the manager who provides services for the waste they generate from the ticket retribution that has been paid. So that the visitor's sense of belonging to the cleanliness and beauty of Urban Forest Park Langsa becomes the role of managers who have been financed by visitors who travel to Urban Forest Park Langsa.

Management of waste generation when leaving the area which is only a container/unit of waste is a problem in the Urban Forest Park Langsa area. Visitor participation cannot be resolved if there is no management participation in managing waste generation when leaving the area, which is another problem based on research documentation.

\section{c. Documentation on seller participation}

Based on the analysis of community participation in waste generation management, it can be seen in the key plan aerial photos in the Urban Forest Park Langsa area. Analysis of community participation, namely sellers who are in the area that produce waste when the initial activity will enter the area, while inside the area, until when leaving the area. The level of merchant participation will be analyzed for the management of waste generation in the Urban Forest Park Langsa area. Analysis of problems during field documentation on the participation of sellers in the management of waste generation in areas that are not following the standard for handling waste generation which will be resolved at the Urban Forest Park Langsa.

Sellers who peddle their wares in the canteen/cafeteria area are the people of Langsa City who pay the kiosk/stalk rental fee to the manager every year/month. There are not so many street vendors selling in the area, all sellers' activities are centered on a predetermined area in the canteen area so that managers can easily handle the management of waste generated by sellers.

The type of waste generated by sellers while in the area is not only in the form of merchant merchandise, the volume of waste produced is no longer suitable for trash containers/bins. Sellers also did not pay attention to the generation of waste that exploded from the trash cans/garbage cans in front of the canteen area which is their main selling area in the Urban Forest Park Langsa area.

Sellers also produce food and beverage waste in the form of food/beverage bottles that have economic value to be sold to used goods collectors. However, it requires more space and energy in classifying it so that cardboard type waste is used as the main type of waste removed from the Urban Forest Park Langsa area. The participation of sellers in the management of waste generation in and out of the area is another problem based on the documentation of researchers at Urban Forest Park Langsa.

\subsection{Waste facility planning for community participation}

The problem that will be expressed by the researchers to achieve the first objective of the study is to analyze community participation in the management of waste generation in Urban Forest Park Langsa. As well as the second objective of the research, namely the planning of waste facilities based on 
community participation using research methods including direct observation and interviews. The planning of trash bins with 3 colors, organic in green, non-organic in yellow and B3 waste in red will be placed in the research area.

The main waste generated in the area is the generation of organic waste in the form of dry leaves and fallen tree branches throughout the Urban Forest Park Langsa area. The emergence of organic waste dominates in every area which makes waste management a top priority, especially those who are waste officers. The organic waste produced is collected at several points in the area and burned in the morning/evening before opening or after the manager closes the Urban Forest Park Langsa area. Management of organic waste generation has not been carried out optimally in the Urban Forest Park Langsa area. The generation of inorganic waste is the second rank waste generated by visitors who buy merchandise from sellers in the Urban Forest Park Langsa area. The generation of organic waste is the second type of waste found in all regions after organic waste. Piles of organic and inorganic waste are often put together by the manager to be burned without any waste management. The same treatment for handling organic and inorganic waste at several points by burning in the morning/evening before or after the manager closed the Urban Forest Park Langsa area.

The next stage of analysis that the researchers did was to use interview research instruments about planning for waste facilities based on community participation in waste generation management in Urban Forest Park Langsa. The interviews conducted were structured interviews with answers from informants then free responses with sufficient time to answer them. Structured interviews will be adapted to the unique characteristics of the informants or informants in the research area. Interviews that will be conducted by researchers are to the people who are in the Urban Forest Park Langsa including managers, visitors, and sellers.

\subsection{Research findings}

The application of the $3 \mathrm{R}$ concept (Reuse, Reduce, and Recycle) as a result of the analysis to obtain the research objective is to plan waste facilities based on community participation in waste generation management in Urban Forest Park Langsa. The implementation of planning for waste management facilities with the $3 \mathrm{R}$ concept includes planning for containers, waste collection points, and/or waste selection, then heading to the Final Disposal Site (TPA). Community participation includes managers, visitors, and traders here, namely only managers as citizen power who have a high level of participation in the participation ladder of Arnstein's theory (1969). Where the manager as a third party (PT. Kuala Langsa Harbor) negotiates with decision-makers, formulates policies, namely the Langsa City government, and shares responsibilities in planning and solving problems faced (partnerships) in the Urban Forest Park Langsa Area.

Based on data verification, important or prominent decisions are used as models for waste generation management planning that are relevant to the research objectives. Then attention is focused on the data obtained, data triangulation is carried out by combining various data collection techniques 
(observation, documentation, and interviews) and data sources in the field so that the following research can be produced:

\section{a. The containers}

The containers provided in the area are planned for 58 series points spread throughout the Urban Forest Park Langsa area (Figure 5.31). The planned container is a plastic trash can made from HDPE (HighDensity Poly Ethylene) which is resistant to extreme temperatures and high humidity in Urban Forest Park Langsa. HDPE trash cans measuring $50 \mathrm{~cm}$ x $50 \mathrm{~cm}$ x $90 \mathrm{~cm}$ with a capacity of 225 liters per barrel.

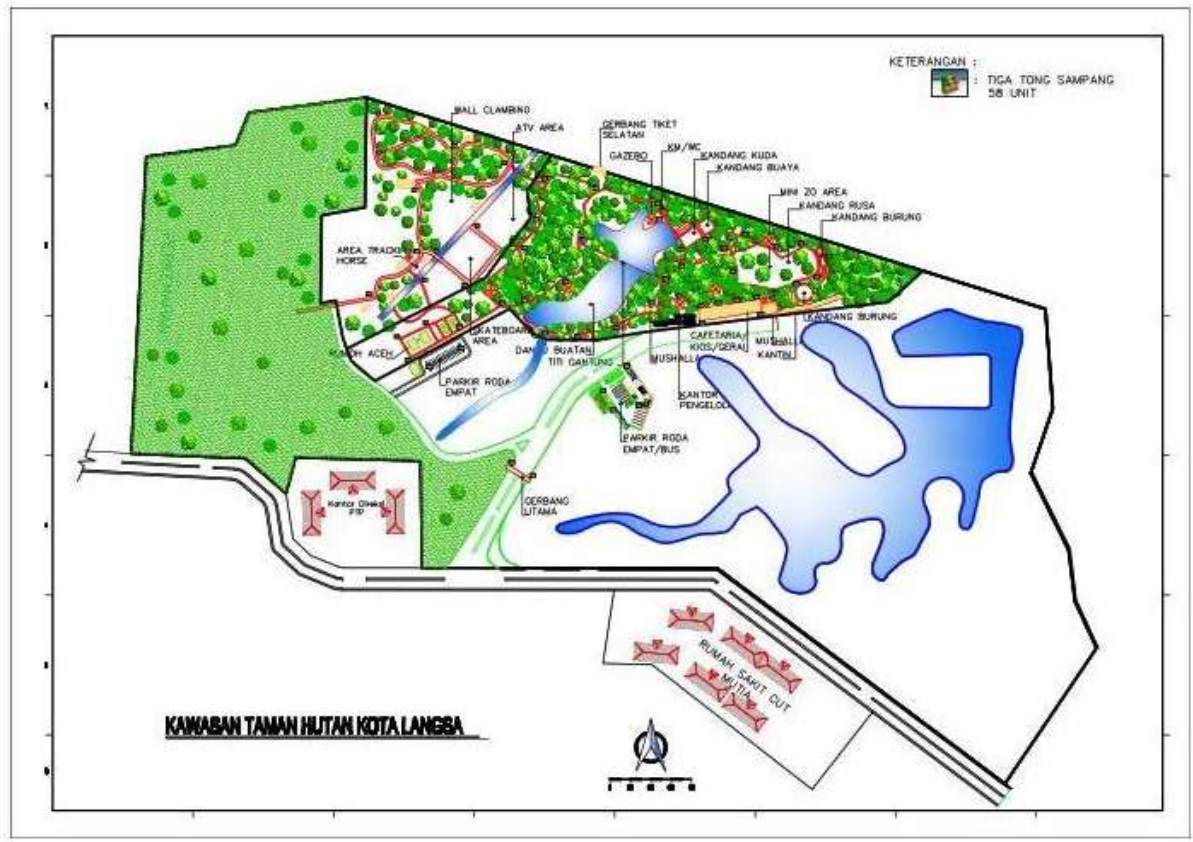

Figure 1: Distribution of trash containers

Each unit of the trash can consist of 2 (two) units consisting of the body of the trash can, and the head/cap of the trash can. Each unit can be opened and closed when the officer collects the waste to be taken to the waste collection and/or sorting point. Each unit of a trash can is assembled into 3 (three) units with color labels according to the type of waste (green; organic, yellow; inorganic, and red; B3 bins). Each unit of a series of 3 (three) trash bins is planned to be covered with a solid wood casing as high as $65 \mathrm{~cm}$ and given a motif to blend with the Urban Forest Park Langsa environment. The use of solid wood trash can casings with motifs to strengthen the structure of 3 (three) series of trash bins (HDPE) to avoid the activities of wild animals (monkeys) which often ruffle the trash cans/containers. A series of 3 (three) containers and their casings are planned to be placed on a $10 \mathrm{~cm}$ thick foundation as the footprint of the container/trash can so that it does not come into direct contact with the ground and as a binder for a series of 3 (three) trash bins. A sticker calling for proper disposal of trash is 
installed on the front of the trash can casing/blanket so that the public gets important information to dispose of waste in its proper place. However, the manager needs to provide an advisory board as a medium of information about the types of waste that are suitable for disposal in a series of 3 (three) trash bins that will be planned.

The series of trash bins are labeled green for organic waste containers, yellow for inorganic waste containers, and red for B3 containers. The color is also the same as the simple canopy made of a $3 \mathrm{~mm}$ iron plate. It is planned to be formed on the back of a series of trash cans that have many functions apart from their shape and beauty. The first function is to prevent rainwater from entering the trash can directly. Second, provide information about the types of waste that may be disposed of in the trash by labeling the words Organic, Inorganic, and B3.

\section{b. Garbage Collection and Sorting}

Places for processing organic waste have been built but have not been maximized by the manager as a community with a high level of participation in the participation ladder according to Arnstein (1969), namely as a partnership. Composting organic waste can maximize the function of the organic waste counting machine that already exists in the Urban Forest Park Langsa area. Based on the results of observations and interviews that organic waste produced in the area is not composted but burned in the morning/afternoon. Burning organic waste can produce methane gas which can interfere with human health. However, reactivating organic waste processing sites can provide benefits for the area itself. Where every month the Mayor of Langsa and his staff plant hundreds of new trees throughout the Urban Forest Park Langsa area.

The process of managing inorganic and B3 waste has not been carried out at all. Planning for waste management facilities in the Urban Forest Park Langsa area by making plans for waste collection facilities will later be planned in the form of Temporary Waste Collection Places (TPS) by sorting inorganic waste and B3 waste (Figure 5.32). All waste that has been classified according to its type is placed in garbage containers and then transported by garbage transport, in the form of garbage carts, garbage tricycles, motorized tricycles, 3-wheeled vehicles, or pick up cars. All organic waste is taken to organic waste processing, while inorganic and B3 waste is taken to temporary TPS located in the Urban Forest Park Langsa area.

The waste management facility that will be planned is a simple building with a wide span as shown above (Figure 5.32). When viewed from the shape, it appears that the building does not heed the aesthetics of the building but prioritizes the function of the use of the building. The building is 24 meters long and 12 meters wide. The building plan includes a collection and sorting area measuring 12 meters x 16 meters and a burning area above the incinerator measuring 8 meters x 12 meters.

Management planning for the generation of inorganic waste and B3 waste (in the form of hazardous materials) can be done by planning a waste sorting facility where the capacity of the waste generated by the area reaches 12 (twelve) tons per year. Containers for 12 (twelve) containers with a capacity of 
1 ton each with waste sorting including 10 (ten) inorganic waste bins and 2 (two) B3 bins. Inorganic trash cans are labeled yellow with details of paper waste, plastic waste, glass bottles, aluminum bottles, plastic bottles, and B3 waste being labeled red.

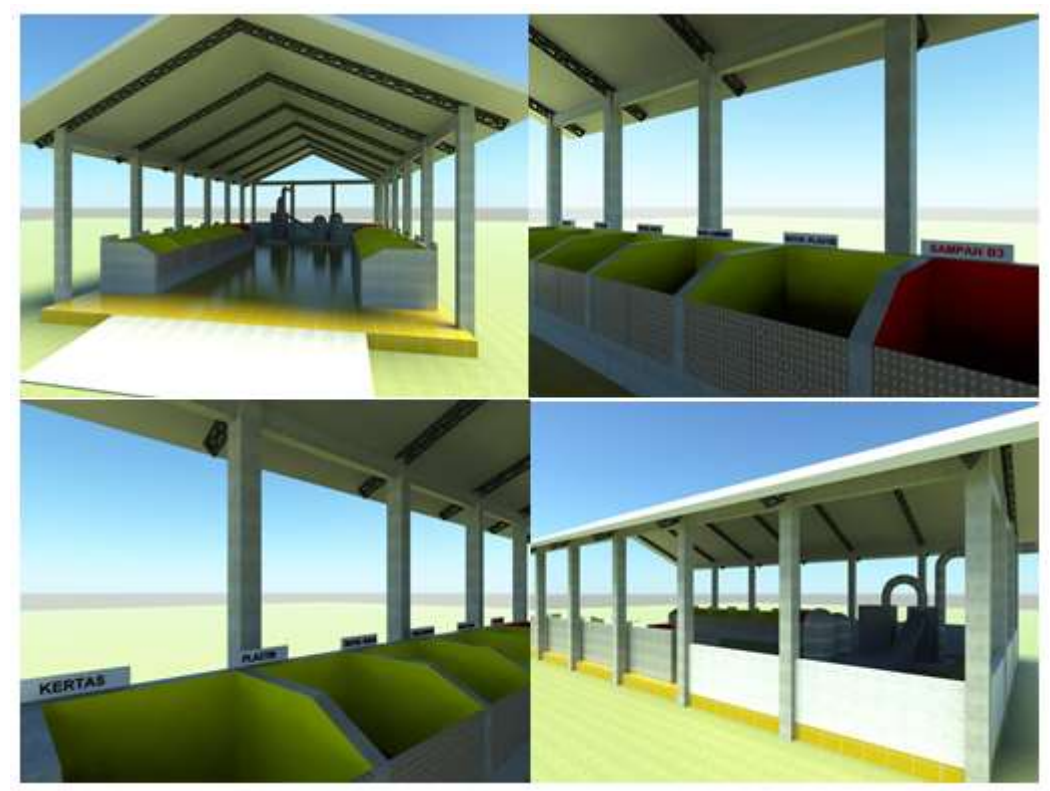

Figure 2: Planning of waste treatment facilities

The building structure consists of the lower structure, the middle structure, and the upper structure. The lower structure uses a tread foundation using a reinforced concrete frame to support the middle structure. The foundation is a very important building structure that is related to the ground to support the frame structure of the building and other parts of the building above it but still pay attention to earthquake resistance standards. The middle structure uses reinforced concrete sloof, columns, and beams. The entire series of iron rods as a building frame covered with concrete is a support for the superstructure. The upper structure is a steel profile frame that can support the support with a span between columns as wide as 12 meters, which is coated with zinc material that functions as a protection from heat, rain, and direct wind. Planning for waste generation management facilities in the form of collection and sorting of waste in the Urban Forest Park Langsa can be built in the area by making special access. So that it can be used as a means of public education in the form of a waste generation model using the $3 \mathrm{R}$ concept in the Urban Forest Park Langsa area.

\section{c. Final Processing Site (TPA)}

Planning a waste management facility with the 3R concept (reduce, reuse and recycle) in measuring and collecting waste in the Urban Forest Park Langsa by reducing or minimizing waste at the beginning, namely when collecting waste in trash containers/bins. Then by sorting waste, as well as waste residues that cannot be composted or recycled are burned in incinerators. 
An incinerator is a useful tool to burn the distribution of waste that cannot be processed or B3 waste that is harmful to the environment. An incinerator is a technology within the limits of making waste at a certain temperature. Even with the dual combustion chamber incinerator combustion technology, it can lower the toxic materials produced in burning waste including carbon dioxide and carbon monoxide. The residue left from incinerator combustion in the form of combustion ash must be further processed if it is to be reprocessed into building materials. However, if there is no processing purpose, the incinerator is immediately taken to the final processing location (TPA).

\section{CONCLUSIONS}

Based on the level of community participation based on the theory of Sherry R Arnstein (1969) that the level of community participation in the Urban Forest Park Langsa can be detailed as follows:

a. The community in the area (the manager) is the level of participation as citizen power where the participation level of the manager is the highest level of participation in the community participation ladder (6/8). The community, namely the manager, has the right to negotiate with decision-makers or the government, by mutual agreement, power is shared between the community, namely the manager as a third party with the government (partnership). For this reason, an agreement was taken to share responsibilities in planning, controlling decisions, formulating policies, and solving problems encountered. This can be seen based on field interviews with visitors and sellers in their participation in waste generation management in Urban Forest Park Langsa.

b. Communities in the area (visitors and sellers) that is the level of participation there is no participation at all (non-participation), the level of participation of visitors and sellers is only the lowest level of participation in the community participation ladder (1/8) where the community is only used as a name (manipulation). This can be seen based on field interviews with visitors and sellers in their participation in waste generation management in Urban Forest Park Langsa.

Based on Tori Sumarto's (2003:113) concept of the level of participation from various theories and experiences in the field of participatory planning. That the level of community participation in the planning of waste facilities is low. The community, namely managers, visitors, and sellers, only witnessed project activities carried out by the government. The public can only provide input either directly or through the mass media, but only for consideration. There is no waste management plan using the $3 \mathrm{R}$ method (reduce, reuse, and recycle) in the Urban Forest Park Langsa area. Waste management in the area is only limited to trash bins. The provision of trash bins/trash cans in the area has provided labels of 4 (four) color sequences and written trash bins for the type of waste (organic waste with green labeling, paper waste with blue labeling, inorganic waste with yellow labeling, and B3 waste). with red labeling) but not effective. Provision of waste containers by labeling 3 (three) color sequences and writing trash cans for the type of waste (organic waste with green labeling, inorganic waste with yellow labeling, and B3 waste with red labeling) can be used as management 
planning waste by using community participation, namely the manager in dealing with waste generation in Urban Forest Park Langsa. Planning for the management of organic waste generation has not been carried out optimally in the Urban Forest Park Langsa area.

Management planning for the generation of inorganic waste and B3 waste (in the form of hazardous materials) can be implemented by planning a waste sorting facility where the capacity of the waste generated by the area reaches 12 (twelve) tons annually. Container for 12 (twelve) containers with a capacity of 1 ton each with waste sorting including inorganic 10 (ten) bins and B3 2 (two) bins). Inorganic waste bins are given a yellow label with details on paper waste, plastic waste, glass bottles, aluminum bottles, plastic bottles, and B3 waste given a red label. Planning of waste management technology facilities by burning in an incinerator. Where the use of this technology must pay attention to several aspects including having technical specifications that are economical, efficient, and effective. The waste management model in Urban Forest Park Langsa is to reduce or minimize waste, from the time of collecting waste in trash containers/bins, by sorting waste, recycling waste, and burning residue that cannot be composted or recycled in an incinerator.

\section{REFERENCES}

Y. Hendra, "Perbandingan Sistem Pengelolaan Sampah di Indonesia dan Korea Selatan," Aspirasi Vol. 7 No. 1, p77-91, Juni, 2016.

A. Kahfi, “Tinjauan Terhadap Pengelolaan Sampah,” Jurisprudentie Volume 4 Nomor 1, p12-25, Juni 2017.

D. Conyers, Perencanaan Sosial di Dunia Ketiga, UGM Press, Yogyakarta, 1991.

S.R. Arnstein, "A Ladder of Citizen Participation," Journal of the American Institute of Planners, Volume 35, p216-224, 1969.

Sumarto and Hetifa Sj. "Inovasi, Partisipasi dan Good governance," Yayasan Obor Indonesia, Bandung, 2003.

A.M. Yusuf, Metode Penelitian Kuantitatif, Kualitatif \& Penelitian Gabungan, Kencana, Jakarta, 2014. Moleong, L.J., Metodologi Penelitian Kualitatif Edisi Revisi, PT. Remaja Rosdakarya, Bandung, 2011. D. Nadjih, et al, "Identifikasi Jumlah dan Faktor Timbulan Sampah Di Kawasan Wisata Malioboro," Jurnal Pembangunan Masyarakat, Vol. 5, No. 1, p.35-43, 2020.

R. Aziz and K.M. Jefri, "Study of recycling potential of solid waste of tourism region of Taman Marga Satwa and Budaya Kinantan (TMSBK) and Taman Panorama dan Lobang Jepang (TPLJ) in Bukittinggi City,”. Proceeding of 5th ACE Conference. Padang, pp 82-90, 2018. 


\section{International Journal of Education and Social Science Research}

\section{Author Profile}

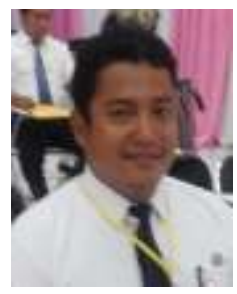

Wan Achmad Adriansyah higher education was taken at the University of North Sumatra in 20042009 majoring in Architectural Engineering. Currently, the author has the opportunity to take postgraduate education (S2) at the University of North Sumatra in the Master Program in Architectural Engineering. 